retention may have been an important factor in retarding this child's growth.

Obstructive apnoea during sleep is not often diagnosed in the United Kingdom, ${ }^{5}$ but there are no good reasons to think that it is a less common condition than in North America. ${ }^{6}$ We believe that it would be diagnosed more often if parents were questioned, and listened to, about sleep and the child was examined while sleeping.

We are grateful to Mrs K Cordwell and the Salford Department of Medical Illustration.

References

${ }^{1}$ Gastaut H, Tassinari A, Duron B. Polygraphic study of the episodic diurnal and nocturnal (hypoxic and respiratory) manifestations of the Pickwick syndrome. Brain Res 1966;2:167-86.

${ }^{2}$ Guilleminault C, Eldridge FL, Simmonds FB, Dement WC. Sleep apnea in eight children. Pediatrics 1976;58:23-30.

${ }^{3}$ Brouillette RT, Fernbach SK, Hunt CE. Obstructive sleep apnea in infants and children. $J$ Pediatr 1982;100:31-40.

4 Daughaday WH. Hormonal regulation of growth by somatomedin and other tissue growth factors. Clin Endocrinol Metab 1977;i:119.

5 Apps MCP, Moore Gillon JC, Stradling JR. Underdiagnosis of obstructive sleep apnoea in Britain (letter). Lancet 1983;i:1054.

${ }^{6}$ McNicholas WT, Tarlo SM, Phillipson EA. Is sleep apnoea more common in North America? (letter). Lancet 1982;i:458.

Correspondence to Dr D A Price, Senior Lecturer in Child Health, Department of Child Health, Royal Manchester Children's Hospital, Pendlebury, Manchester M24 1HA.

Received 28 September 1983

\title{
Transverse myelitis associated with Mycoplasma pneumoniae infection
}

\author{
P I MACFARLANE AND V MILLER
}

Booth Hall Children's Hospital, Manchester

SUMMARY A case of acute transverse myelitis associated with respiratory infection by Mycoplasma pneumoniae is described. Circulating antibodies to myelin were detected suggesting that mycoplasma related neurological damage is mediated by producing an immunological myelopathy.

Neurological complications of infection with $\mathrm{Myco}$ plasma pneumoniae have affected the meninges, cerebellum, cerebrum, spinal cord, and nerve roots. ${ }^{1}$ The pathogenesis of the neurological disorder is uncertain. Evidence suggests an immunological mechanism acting against myelin and nerve cells. ${ }^{2}$

We report on a child with acute transverse myelitis and aseptic meningitis. There was evidence of production of $M$ pneumoniae antibody in the blood but no evidence of local antibody synthesis in cerebrospinal fluid (CSF). Antibodies to myelin were shown in blood.

\section{Case report}

A 14 year old girl presented 10 days after onset of rhinorrhoea, cough, and intermittent pyrexia. Two days before admission she had developed ascending paraesthesia and numbness in both legs. This progressed to total paraplegia. Abnormal clinical findings were confined to the nervous system. She showed mild meningism but was fully conscious. The functions of the cranial nerves, cerebellum, and arms were normal. A complete flaccid paraplegia with areflexia and bilateral extensor plantar responses was noted in her legs as was loss of sensation up to her mid abdomen (level T9-10). Her bladder was palpable. Position and vibration sense was absent in both legs. A chest radiograph showed patchy consolidation in the left lower lobe of the lungs. An extrinsic compressive cord lesion was excluded by myelography.

CSF collected during the procedure contained 50 leucocytes $/ \mu$ l $(30 \%$ polymorphs, $70 \%$ monocytes). A low CSF glucose concentration $(2.4 \mathrm{mmol} / \mathrm{l}(43$ $\mathrm{mg} / 100 \mathrm{ml})$, blood glucose $6 \cdot 3 \mathrm{mmol} / 1(114 \mathrm{mg} / 100$ $\mathrm{ml})$ and raised protein concentration $(1.3 \mathrm{~g} / \mathrm{l})$ were noted. CSF was sterile. An initial blood film showed considerable autoagglutination of red cells and total white cell count of $12.5 \times 10^{9} / 1(82 \%$ neutrophils, $15 \%$ lymphocytes, $3 \%$ monocytes). Mycoplasma related acute transverse myelitis was provisionally diagnosed.

Treatment was started with erythromycin and prednisolone. Bladder catheterisation and rectal washouts were required. Over the first 48 hours the 
Table Selected laboratory investigations

\begin{tabular}{|c|c|c|c|c|c|}
\hline \multirow{2}{*}{$\begin{array}{l}\text { Day in } \\
\text { hospital }\end{array}$} & \multirow{2}{*}{$\begin{array}{l}\text { Erythrocyte } \\
\text { sedimentation } \\
\text { rate } \\
\text { ( } \mathrm{mm} \text { in first hour) }\end{array}$} & \multicolumn{2}{|c|}{ Serum cold agglutinin titres } & \multirow{2}{*}{$\begin{array}{l}\text { Serum } \\
\text { mycoplasma } \\
\text { titres }\end{array}$} & \multirow{2}{*}{$\begin{array}{l}\text { Cerebrospinal fluid } \\
\text { mycoplasma } \\
\text { titres }\end{array}$} \\
\hline & & Room temperature & $4^{\circ} \mathrm{C}$ & & \\
\hline 1 & 33 & $1: 64$ & $1: 512$ & $1: 160$ & $1: 4$ \\
\hline 9 & 8 & $1: 8$ & $1: 128$ & $1: 320$ & nd \\
\hline 16 & nd & negative & $1: 64$ & $1: 320$ & nd \\
\hline 23 & nd & negative & $1: 64$ & nd & nd \\
\hline 30 & 9 & negative & $1: 32$ & nd & nd \\
\hline
\end{tabular}

nd indicates not done.

sensory loss progressed upwards to mid thoracic level (T4) but then regressed. Leg power began to return on the fifth day in hospital. Spontaneous micturition returned by three weeks. By four weeks she was able to walk with help. Two months later neurological function was normal.

The Table shows the results of sequential investigations. Serum antibody titres to cytomegalovirus, influenza $A$ and $B$, orthomyxovirus $A$ and $B$, adenovirus, respiratory syncytial virus, and chlamydia yielded normal results. Measles, mumps, varicella, and rubella viruses were not isolated from viral cultures of nasopharyngeal secretions, faeces, urine, or CSF. A monospot for glandular fever was negative. A specific culture medium for mycoplasma was not available. Serum cold agglutinin titres, which were initially high, fell during recovery. Antibody titres to $M$ pneumoniae increased during convalescence. CSF mycoplasma antibody was present to a titre of $1: 4$. The IgG index, which is an indicator of total CSF IgG, was marginally raised $(0 \cdot 76$, normal 0.7$)$. The ratio of serum to albumin concentration in CSF was low (45:1, normal 200:1), indicating that the barrier between blood and CSF was not intact. The mycoplasma antibody present in CSF was probably a reflection of 'leakiness' rather than true intraspinal antibody synthesis.

Strongly positive serum antibodies to spinal myelin (titre of $1: 60$, control $1: 10$ ) and cerebellar myelin (1:40) were detectable by indirect immunofluorescence techniques using delipidated nervous tissue from rats. Antimyelin antibodies were not detectable in CSF.

\section{Discussion}

Mycoplasma infection was diagnosed on the basis of prodromal symptoms, radiological pulmonary signs, and cold agglutinin production even before serological confirmation became available. Cold agglutinins, though suggestive of mycoplasma infection, are not diagnostic and have been shown in other viral pneumonias. Acute transverse myelitis seems to be a rare form of mycoplasma related neurological disease. ${ }^{1}$ The low CSF glucose concentration noted in our patient has been reported in some other cases. $^{3}$

Although antibodies to $M$ pneumoniae have been reported to be present in the CSF of two other patients with this condition, ${ }^{34}$ the integrity of the barrier between blood and CSF was not reported. The abnormally low ratio of serum to albumin concentration in CSF in our patient suggests that antibody in the CSF was detectable because of leakage from serum rather than by synthesis within the spinal cord or CSF. There has been only one previous report giving evidence of direct invasion of the central nervous system by $M$ pneumoniae. ${ }^{5}$

Antibodies to myelin were present in the serum of our patient. This supports the hypothesis that mycoplasma related neurological damage is mediated by producing an immunological myelopathy. Antibodies induced by mycoplasma infection are known to cross react not only with human erythrocyte I antigen (producing the cold agglutinin effect) but also with other tissues including that of the brain. ${ }^{6}$ It is not possible to say whether the use of steroids had any beneficial effect on these immunological mechanisms. Neither has the use of plasmaphoresis to remove antimyelin antibodies, as proposed by Cotter et $a l,{ }^{4}$ been proved to be beneficial.

Erythromycin is effective in treating mycoplasma respiratory infection but it is not known whether the drug alters the neurological course of infection. As evidence suggests an immunological mechanism rather than direct invasion, the poor penetrability of erythromycin into the CSF may not be a disadvantage in this respect.

\footnotetext{
References

${ }^{1}$ Lerer RJ, Kalavsky SM. Central nervous system disease associated with mycoplasma pneumoniae infection. Pediatrics 1973;52:658-68.

2 Clyde WA, Jr. Neurological syndromes and mycoplasmae infections. Arch Neurol 1980;37:65-6.
} 
${ }^{3}$ Klimek JJ, Russman BS, Quintiliani R. Mycoplasma pneumoniae meningoencephalitis and transverse myelitis in association with low cerebrospinal fluid glucose. Pediatrics 1976;58:133-5.

4 Cotter FE, Bainbridge D, Newland AC. Neurological deficit associated with mycoplasma pneumoniae reversed by plasma exchange. Br Med J 1983;286:22.

5 Fleischauer P, Hübe NU, Mertens H, Sethi KK, Thürmann D. Nachweis von mycoplasma pneumoniae im liquor bei akuter polyneuritis. Dtsch Med Wochenschr 1972;97:678-82.
6 Biberfeld G. Antibodies to brain and other tissues in cases of mycoplasma pneumoniae infection. Clin Exp Immunol 1971;8:319-33.

Correspondence to Dr V Miller, Medical Department, Booth Hall Children's Hospital, Charlestown Road, Blackley, Manchester M9 2AA.

Received 14 September 1983

\title{
Prophylactic ethamsylate for periventricular haemorrhage
}

\author{
R W I COOKE AND M E I MORGAN \\ Regional Neonatal Intensive Care Unit, University of Liverpool, Liverpool Maternity Hospital, Liverpool
}

SUMMARY Drug prophylaxis with ethamsylate for periventricular haemorrhage in very low birthweight infants significantly reduced the incidence of periventricular haemorrhage in survivors. A reduction in abnormalities at follow up and in insertion of ventriculoperitoneal shunts was also noted.

Although there has been a rapid increase in survival of very low birthweight infants requiring intensive care, neurodevelopmental sequelae remain a problem in some. Improvements in non-invasive techniques for imaging the neonatal brain have made it possible to diagnose periventricular haemorrhage (PVH) and some ischaemic lesions in vivo. ${ }^{1}$ The association of PVH with neurodevelopmental sequelae at follow up is well documented. ${ }^{2}$ Drug prophylaxis of $\mathrm{PVH}$ with phenobarbitone or ethamsylate has been claimed to reduce the incidence of PVH on ultrasound examination, but no information on outcome is available. ${ }^{34}$ We report follow up data in a group of ventilated infants of very low birthweight treated prophylactically with ethamsylate during a 2 year period and compare these infants with a similar group of untreated infants admitted during the same period.

\section{Patients and methods}

A double blind, randomised, placebo controlled trial of ethamsylate prophylaxis of PVH was carried out at this hospital in 1980-1, and the results were published elsewhere. ${ }^{4}$ For the following 6 months no effective prophylaxis was given, and at a later date open use of ethamsylate began (in all ventilated infants $<1500 \mathrm{~g}$ ). To have enough infants to form a follow up study, all very low birthweight infants admitted to the unit over a two year period were considered, whether they were included in the original trial or not. Only infants born in this hospital and weighing 501-1500 $\mathrm{g}$ at birth; who were free from PVH on initial ultrasound examination; ventilated for at least 6 hours; free from lethal congenital malformations, meningitis, or Down's syndrome; and who survived to be followed up for at least one year were included. Forty three such infants had been treated with ethamsylate 12.5 $\mathrm{mg} / \mathrm{kg} 6$ hourly for 16 doses beginning within two hours of birth. Forty eight had not been treated with ethamsylate and formed the control group. Table 1 gives clinical data for the group receiving treatment and for the controls.

Follow up examinations were performed at this unit at regular intervals, except in a few cases where for social or economic reasons follow up examination had to be performed at the referring district hospital. All infants were followed for between one and three years and were assessed, as appropriate, by neurological examination, Denver Developmental Screening test, and Stycar tests of hearing and vision. Infants identified as having abnormalities were referred for specialist developmental, ophthal-

Table 1 Clinical data for infants receiving treatment and for controls

\begin{tabular}{llcl}
\hline & $\begin{array}{l}\text { Infants receiving } \\
\text { ethamsylate } \\
(n=43)\end{array}$ & $\begin{array}{l}\text { Controls } \\
(n=48)\end{array}$ & $P$ \\
\hline Mean birthweight (g) & 1082 & 1125 & $\mathrm{~ns}$ \\
Mean gestation (weeks) & $29 \cdot 1$ & $28 \cdot 8$ & $\mathrm{~ns}$ \\
Apgar score <3 & 5 & 10 & $\mathrm{~ns}$ \\
$\begin{array}{l}\text { Arterial carbon dioxide } \\
\text { pressure }>8 \mathrm{kPa}^{*}\end{array}$ & 10 & 11 & $\mathrm{~ns}$ \\
pH <7.15* & 12 & 9 & $\mathrm{~ns}$ \\
Pneumothoraxt & 6 & 9 & $\mathrm{~ns}$ \\
PVH & 10 & 28 & $<0.01$ \\
\hline
\end{tabular}

* during first 48 hours

$\dagger$ during first 72 hours 